\title{
Human dignity and biomedical ethics from a Christian theological perspective
}

\begin{abstract}
Author:
Ulrich H.J. Körtner ${ }^{1,2}$

Affiliations:

${ }^{1}$ Institut für Systematische

Theologie und

Religionswissenschaft,

Universität Wien, Austria

${ }^{2}$ Department of Systematic

Theology and Ethics,

University of Pretoria,

South Africa

Note:

This article was originally presented as a paper on the workshop 'Dignity, empirical, cultural, and normative dimensions' at the Zentrum für Forschung (ZiF), University of Bielefeld Germany, held on 16 July 2010. Prof. Dr Ulrich Körtner is participating as a research associate of Prof. Dr Johan Buitendag, Dean of the Faculty of Theology at the University of Pretoria, South Africa.
\end{abstract}

\section{Correspondence to:}

Ulrich Körtner

Email:

ulrich.koertner@univie.ac.at

Postal address:

Evangelisch-Theologische Fakultät, Universität Wien, Schenkenstr. 8-10, 1010

Vienna, Austria

Dates:

Received: 09 Sept. 2010

Accepted: 24 Nov. 2010

Published: 11 July 2011

How to cite this article: Körtner, U.H.J., 2011, 'Human dignity and biomedical ethics from a Christian theological perspective', HTS Teologiese Studies/Theological Studies 67(3), Art. \#953, 8 pages doi:10.4102/hts.v67i3.953

(C) 2011. The Authors. Licensee: OpenJournals Publishing. This work is licensed under the Creative Commons Attribution License.
The argument of human dignity plays an important role in current debates on human rights and their relevance in modern biomedicine. When discussing the contribution of Christian theology to current debates on human dignity and human rights the thesis is not that the modern idea of human dignity depends on a theological grounding. Also, it is not the task of theology to legitimate rights as Christian a posteriori. We do not need to deduce modern human rights from theological doctrines. The theological challenge is to find an access for Christians from their belief to the modern idea of human rights and human dignity and to discuss the contribution which theology and the churches can make to further development of human rights. The Christian image of man, which serves as the foundation for the church position on bioethical topics in the German-speaking context, is a mix of biblical motives, a Kantian interpretation of the concept of human dignity and an interpretation of the German constitutional law inspired by the Catholic tradition of natural law. The following presented theological understanding of human dignity, in contrast, was inspired by the insights of the Pauline doctrine of justification and its Protestant reinterpretation.

\section{The historicity and the historical transformation of the idea of man}

'The dignity of human beings is not untouchable.' This is the thesis of the German philosopher Franz Josef Wetz (1998). If we think about the intense controversy concerning odds and limits of modern biomedicine he seems to be right (cf. Körtner 2010:79ff). It becomes increasingly difficult to understand what we mean by the value and the term of human dignity, even though the protection of human dignity and of human rights is supported by everyone. Even in a country such as Germany, where the indefeasibility of human dignity is part of the constitutional law, there is an open debate on the question, when the existence of human beings and how long human life has to be protected as the life of a human person.

Indeed, the idea of human dignity cannot be derived exclusively from the Christian idea of man; nevertheless, Christian anthropology belongs at the roots of this idea. That is why it sounds dubious to some philosophical traditions. Appealing to human dignity sometimes is criticised as merely rhetorical and the Christian justification is seen as an example of religious particularism. It also must be seen that the understanding of dignity in Christian tradition differs from a modern view of human dignity as it is held in the context of human rights. In fact, not only general values but also ...'fundamental values', such as human dignity and human rights are the result of historical processes and are based on a sociopolitical consensus. Their concrete interpretation leads to recurring conflicts, as shown in the bioethical discussion about the ontological and moral status of the embryo and in the question about the ethical permissibility of embryonic stem cell research and pre-implantation genetic diagnosis (PGD). Even the reference to Immanuel Kant's (2000) 'Groundwork of the metaphysics of morals' is unable to introduce a character of contingency to the debate on values. In this work, Kant distinguishes between human dignity as an elementary value opposed to any economic logic of exchange and other possible values. The reference to the human being as an end in itself, as asserted by Kant, finds its correspondence in the biblical myth of the creation of humans in the 'Image of God'. However, this does not answer the controversial question about the beginning of human life or when human life can be defined as the life of a new human being.

Differing positions on bioethical questions exist both in theology and the church, even though both subscribe to the common Christian idea of man. Values and even human dignity do not constitute an objective reality, but rather 'institutional facts', as Ortrun Riha (2002) states in reference to Axel Bauer, defining the interpretability of values more closely:

The interpretability of values, that is generally given, is susceptible to functionalization. On the other hand, the interpretability allows a society with concrete motives and experiences to decide in favour of or against certain contents.

(Riha 2002:728) 
But this interpretability is a question of social consensus and not of a metaphysical value system.

However, this does not imply that the reference to arguments based on human dignity in bioethics and in biomedical ethics is obsolete in general. Such arguments fulfil an orientating function but do not have the normative power to solve concrete ethical problems. There is no unanimous agreement about the question of what constitutes a human being. Just as the many ideas of man differ between the past and present, so too do the corresponding ethical conceptions. Stereotypically talking about the idea of man, for example the Christian one, is certainly an ahistorical construction. Not only is there no Christian or humanistic idea of man (because they do not exist in that form), both of these ideas are subject to transformation processes, which are the result of fundamental debates in the age of Enlightenment. These transformation processes also have strong relations to the achievements made in modern natural and human sciences, as well as to societal upheavals such as the transition from the agricultural society to the industrialised society and further, to the postindustrial service and knowledge-based society of today.

Furthermore, there are significant differences between the various Christian confessions, not only with respect to dogmatic but also to anthropological questions. These differences can be seen in the divergent notions of nature, the diverse understanding of human freedom and sin. This has to do with the fact that the answers of churches and individual Christians to ethical questions may vary. The Christian concept of human beings holds a certain plurality that partially exists even across confessions. In this respect, it is more appropriate to talk about Christian ideas of man rather than of one Christian idea of man. Different concepts of the image of humanity are the product of complex processes of cultural and religious hermeneutics.

Therefore, it is misleading to ask for how much longer the technological progress will (still) be compatible with a certain image of humans. The question, rather, is whether an ideological or religious tradition is able to deal productively with historical changes and is capable of reinterpreting outdated traditions in order to allow modern human beings to interpret their being under the present conditions in a meaningful way. Certainly, a thoughtful anthropology still has a critical function in an ethical perspective. Critique and hermeneutics stand in a mutual dialectical interdependence (Körtner 2004, 2005:23ff). ${ }^{1}$ This does not imply that technological progress has to be accepted without critique. In the productive field of hermeneutics and critique, the ambivalences of this historical process have to be studied thoroughly.

Therefore, it might be helpful to introduce the distinction between technical knowledge of disposition and knowledge

1.The dialectical interdependence of hermeneutics and critique of technique is not sufficiently attended by the heuristic of fear proposed by Jonas (1984:63ff). of orientation at this point. Basic orientation for our lives and our actions is not found in abstract principles but rather in stories, metaphors and symbols that create meaning. The belief in creation and the certitude of one's own createdness is situated on this level.

The question of a critique of technology is thus the following: where are the ethical limits beyond which science and technology turn inhuman? The hermeneutical problem of technology is: what does it mean for the self-understanding of the human person, if they have to understand themselves as a technical artefact produced by others? How can the concept of human dignity still be meaningful under such conditions? What does that mean for the notion that humans are created in the image of God, which is so fundamental for Jewish and Christian tradition? Will the human person still find a way to retain the personal faith that he is created by God 'with all creatures' (Luther 1930:510) under the theological conditions of their becoming human?

If the biblical belief in creation claims to be true, then it has to be valid under the conditions of modern biomedicine. If the conviction of humans being created in the image of God becomes superfluous with the use of certain technologies of reproduction, then the story of creation turns into an obsolete myth. ${ }^{2}$ That must be said against those who argue that humans are playing God by using modern technologies of reproduction and genomics, but also against those who argue that biomedical progress refutes the existence of a divine creator. However, natural science and religious belief in creation look at the nature of human beings from a different angle. They represent diverse language games. For a certain understanding in faith of our very existence lies in the discourse about the creation of human beings in the image of God, which is by no means outdated but is still able to serve as a tool for human self-interpretation.

When discussing the contribution of Christian theology to current debates on human dignity and human rights, the thesis is not that the modern idea of human dignity depends on a theological grounding. Also, it is not the task of theology to legitimate human rights as Christian a posteriori. We do not need to deduce modern human rights from theological doctrines. The theological challenge is to find an access for Christians from their belief to the modern idea of human rights and human dignity and to discuss the contribution which theology and the churches can make to further development of human rights (Huber \& Tödt 1977:158).

\section{Problems of translation}

The discussion about the consistence of arguments using the principle of human dignity, and also about their possible religious background, is an example for the basic problems in rendering Christian anthropology accessible to the contemporary bioethical discourse in a pluralistic society. The problem of bi-linguality, after all, plays an important role 2.Cf. The famous 'obsolete' in Bultmann (1988:16). 
not only in bioethics but also in other fields of social ethics; it has been addressed, in particular, by the different theories of 'public theology' (Bedford-Strohm 2008).

Translating is the basic category of all hermeneutics. Each translation from one language into another involves an interpretation, just as, conversely, every act of cognition also involves an act of translation, even when no diversity of languages is to be overcome. Every process of understanding involves a translation, insofar as understanding requires an appropriation of what is heard or read into one's own life world. The problem of translation is therefore essential for hermeneutics because no interpretation is possible without such an application to one's own life world.

However, every understanding is always an 'understandingdifferently' and each translation introduces shifts in meaning, imposing either a linguistic gain or loss. A one-toone translation, whether from one language into another or from one sociocultural context into another, is impossible. Each translation confronts an inerasable otherness and alienness which can be denied only at the cost of doing violence to the text. Thus every translation confronts the problem of the intranslatable:

Wherever a text is translated into another language, the resulting text is not simply itself, but it also does not merely refer to another. The translation is the otherness of the translated text; through translation the translated text is present, and yet it remains withdrawn.

(Figal 2006:57)

What thus holds generally for hermeneutics and translation also holds for the translation of religious or theological propositions into nonreligious contexts. A good example of this problem was presented by the debate on de-mythologising the Gospel, as initiated by Rudolf Bultmann (1988). He made visible the limits of the translatability of a mythical way of thinking into a nonmythical one when he declared that the discourse on 'God's acting' is theologically inescapable. Bultmann even posed the question of whether his concept of an existential interpretation of the New Testament would not have to retain a 'mythological residuum' (Bultmann 1988:63). Similar problems result from Dietrich Bonhoeffer's (1998) programme of a nonreligious interpretation of biblical or Christian concepts, which remains fragmentary but has powerfully influenced contemporary Protestant theology.

But there is the question of whether a complete translation of theological into nontheological propositions would even profit the bioethical discourse in a pluralist society. Were one seriously to exclude religious reasonings as nonuniversalisable group morality from the larger liberal discourse in society, this would force citizens, whenever they participate in public moral decision-making, to deny those religious background convictions which nurture their moral sensitivity, and which open their eyes to the moral relevance of what is decided.

Within the German bioethical discourse, it is (of all things) the philosopher Jürgen Habermas (2009), who, whilst also an advocate of the Enlightenment-inspired critique of religion, insists on the surplus value offered by religious linguistic and tradition residua. This might at first sound surprising. Habermas (1988:23) is convinced 'that we as Europeans' cannot even adequately comprehend 'concepts such as morality, ethos, person and individuality, freedom and emancipation ... unless we internalize the substance of their eschatological Jewish-Christian progeny'. Habermas (1988) supposes - at least in a preliminary sense - the impossibility to translate central contents of religious belief and thought:

As long as religious language carries inspiring, even unrenounceable semantic substance which, at least so far, has not been adequately captured by the language of philosophy and which still awaits translation into founding discourses, philosophy, even in its post-metaphysical form, can neither replace nor suppress religion.

(Habermas 1988:60)

Accordingly, in the bioethical debate concerning the life of the human embryo as well as contemporary eugenics, Habermas (2001a:59ff) refers to the category of the 'un-disposable'. At the same time he decidedly opposes any attempt to resacralise nature (Habermas 2001a:48, 51).

Of course, one may ask whether Habermas, who declares himself to be decidedly 'religiously unmusical' (Habermas 2001b:30), understands the language of the Christian tradition in terms of the Gospel or merely in terms of the voice of the law. And those who would like to pocket Habermas for the sake of a rehabilitation of religion and for a critique of previous secularisation theses should not overlook the fact that he takes suppression of religion to be impossible only for the time being and that he surely has not abandoned it as a distant goal. What Hegel advocated as the sublation of religion into philosophy merely becomes postponed until a better day.

The role of a specific religious language on the political plane of biopolitical debates in Germany differs considerably from that in the USA:

While in the USA, the Catholic Church and the fundamentalist churches presented the issue of stem cells in terms of a conflict concerning the secular or religious character of the USA, and consciously and explicitly linked this issue with the problem of abortion, thus - as one could almost say - ingratiating themselves with the advocates of stem cell research, in Germany the whole debate lacked any overt religious dimension, as well as any very prominent link to the problem of abortion or to the rights of embryos.

(Gottweis \& Prainsack 2002:428)

Thus, in Germany, the churches themselves scrupulously avoided, and still avoid, conceiving of embryo protection primarily in religious terms. They take particular care to present that issue as a complex ethical-philosophical problem, as well as one related to constitutional law. In the USA, the societal polarisation involved the societal forces of fundamentalism and medical progress, whilst in Germany, the political conflict was staged between representatives of human rights and social solidarity on the one side and those concerned with Germany as a location for business and 
research on the other. In addition, the churches in Germany proceed within the framework of a state-church cooperation model, whilst the USA endorses (at least on the federal level) a strict separation between state and church, thus imposing self-assertive independence in the realm of their public language, even on the historically dominant denominations and Free Church types.

\section{Human dignity and biblical images of man}

In the context of the mentioned hermeneutical problems of the bioethical discourse, the grounding of the church statements on the Bible must be noted. However, they deal with it in an eclectic way that demands theological critique (HeimbachSteins \& Steins 2001:98). First of all, one has to acknowledge that neither the biblical tradition in the Old Testament nor that in the New Testament contains the idea of indefeasible human rights and that a biblical understanding of dignity is not identical with the modern juridical and philosophical concept of human dignity.

The argument in modern theology that identifies the concept of 'human dignity' as a secular version of the creation in the 'image of God' is based on Genesis 1:27: 'So God created man in his own image, the image of God he created him.' The stereotypical citation of this Bible verse, the unreflected equation of the image of God with the equivocal concept of person, and the smooth transfer of this concept onto blastocysts can hardly be considered the result of solid exegesis. There are no signs of a thorough engagement with the scientific biblical exegesis in the ecumenical texts on the issue of bioethics. Such exegesis would point out the complexity of biblical assertion at the beginning of life (Lindemann 2001; Utzschneider 2002).

The scientific exegesis shows that the idea of the 'image of God' is not generally found in the Bible, but constitutes a pointed remark in the Old and New Testaments, as well as in the Jewish Bible, which plays only a marginal role. The systematic-theological weight of this remark should not be lowered, but it has to be pointed out that the Bible (especially the Old Testament) speaks of the beginning of life 'not only on the level of theological reasoning, but more specifically, on the level of the perception and experience of daily phenomena such as procreation, pregnancy and birth' (Utzschneider 2002:136). To learn from the Bible means to learn how theological statements are embedded in the concrete context of everyday life.

It is exegetically questionable to inscribe ontological or metaphysical basic assumptions into biblical texts in order to use them in a systematic-theological interpretation of biblical theology. For example, Psalm 139 says:

For you formed my inward parts; you knitted me together in my mother's womb. I praise you, for I am fearfully and wonderfully made. Wonderful are your works; my soul knows it very well. My frame was not hidden from you, when I was being made in secret, intricately woven in the depths of the earth. Your eyes saw my unformed substance; in your book were written, every one of them.

(Ps 139:13-16)

This is no scientific description of the different stages of the embryo in the modern sense, but rather a hymnic language, religious poetry.

The same applies to the book of Job, even if a grievance rather than praise to the Creator is uttered:

Your hands fashioned and made me, and now you have destroyed me altogether ... You clothed me with skin and flesh, and knit me together with bones and sinews. You have granted me life and steadfast love, and your care has preserved my spirit ... Why did you bring me out from the womb? Would that I had died before any eye had seen me and were as though I had not been, carried from the womb to the grave.

(Job 10:8, 11-12, 18-19)

Texts such as Psalm 139 and Job 10 cannot be adopted easily for church positions about bioethical issues. To discuss the ontological and moral status of the embryo by abstracting from concrete situations contradicts biblical texts particularly. The Bible sees the human person as fundamentally relational, whose incarnation and life are a process and a pattern of interaction.

Church statements often ignore the fact that the Christian Old Testament is the 'Bible' of the Jewish people. The Jewish exegesis of the said passages of the Bible, which are used by Christians to argue for the personal status of embryos or even fertilised human eggs, varies considerably from church documents. According to Jewish opinion and argued based on the Jewish Bible, birth is the decisive moment of the beginning of human life. Thus, different positions are applied to issues such as the research of embryonic stem cells and PGD. The answers given are in contradiction to the magisterial position of the Catholic Church, but converge with that of some Protestant ethicists. Protestant theology's focus on scripture allows for perceiving the different views on the beginning of life. The biblical basis of a Christian anthropology therefore is not as unambiguous as the church statements insinuate.

The beginning of life is a multidimensional event from a biblical perspective. There is a social, a biological and a (creation-)theological dimension:

1. The human person emerges from the intimate community of the parents, develops in the mother's womb and brings his life into the larger community of the family and kin. He is embedded in this community from the moment of procreation (social dimension). 2. The beginning of life is tied on material, one might say 'natural' substances, semen and the mother's womb. This is the material environment out of which, in a technical metaphor ... (see Dt 25:9) the human person is 'constructed' (biological dimension). ${ }^{3}$ 3. The womb finally is the discrete place, where through divine action, in any case through prodigious and intangible way the individual person comes about; the person who later on will say 3.cf. Deuteronomy 25:9, where the procreation of a child is compared to the construction of a house. 
' $\mathrm{I}$ ' to himself ('creation-theological' dimension). The beginning of life is no isolated moment in all three dimensions. It is not a point in time but rather a phase of life and a process, in which the human person gets his biological form, is integrated through his parents into a social context and - retrospective - receives through God his personality, individuality and dignity.

(Utzschneider 2002:139f)

As such, God's act of creation cannot be identified or reduced to the biological act of procreation.

The Christian image of man, which serves as the foundation for the church position on bioethical topics in the German speaking context, is a mix of biblical motives, a Kantian interpretation of the concept of human dignity and an interpretation of the German constitutional law inspired by the Catholic tradition of natural law. The following theological understanding of human dignity, in contrast, is inspired by the insights of the Pauline doctrine of justification and its Protestant reinterpretation (Anselm 2001; Dabrock, Klinnert \& Schardien 2004)

\section{Debating man and debating God}

A couple of years ago, James D. Watson, who, together with Francis Crick, had discovered the double helix structure of the DNA in 1953 and thus created the foundation of the modern genetic technology, described the Christian image of man as a disruptive factor for research. He added that the reference to a Creator God and his commandments justify unnecessary suffering, which can be avoided through gene technology and eugenics (Watson 2000:55). The philosopher Ronald Dworkin (1999) understands fears about the danger of eugenical abuse of gene technology. The alternative, however, would be an 'irresponsible cowardice to face the unknown' (Dworkin 1999:17). The possible risk of abuse is outweighed by the hope to reduce the number of genetic defects and deformations and possibly to improve desirable traits such as intelligence.

It would be wrong to be morally enraged about this superhumanism or transhumanism without providing counter arguments. Furthermore, it would be theologically fatal to withdraw to the safe domain of faith. In the ethical discourse of a pluralistic society, it is not sufficient to recite religious certainties as decisionist confessions. There is no rational final foundation for faith; however, there are good reasons to be put forward with reasonable arguments to support positions founded in faith.

No genuinely theological reasoning is necessary to problematise a reductionist image of human beings, which sometimes is deduced from the insights of molecular biology. The question of the essence of man cannot be answered in a biological fashion. To answer this question with reference to man as animal rationale defines the human person as an animal and reduces the essence of man to a differentia specifica, which distinguishes him from other animals. One thing is clear: the debate about the essence of man is not only an interesting question for a philosophical seminar. Different understandings of the essence of man will ultimately decide about the right of existence of human beings.

The question of the image of man does not only deal with a definition of the essence of man; anthropology also searches for reasons to justify the existence of man. If individual human beings cannot justify themselves with respect to their right to existence, for example because they are not born yet, because they are mentally challenged, because they are in a coma or because they have permanently lost consciousness, who or what will justify their right to live?

The answer provided to this question in the Protestant tradition of Christianity is: God justifies the life of each human person. The human person is justified by God and because of that they do not have to justify their own existence. This is the main point brought into the ecumenical discussion about the Christian image of man by the Protestant Churches and this can be seen as the theological grounding of the idea of human dignity and indefeasible human rights as universal, categorical and individual. ${ }^{4}$ The Pauline thesis that no one simply can be compared to God for everyone, without exception, depends on God's grace, ${ }^{5}$ can be inverted into the positive consequence that all human beings are equal. As Paul says in the context of the doctrine of justification: 'There is no personal favouritism with God', which means that God does not show preference of certain individuals. In a similar way, the letter of James demands that Christian believers must not have the faith of Jesus Christ with respect of person (Ja 2:1). This means that all members in the Christian community, the poor as well as the rich, are worthy of the same respect, which can be understood as the ethical consequence of the insight in everyone's need for God's forgiveness and grace. In this idea we may see an analogy to the idea of the impartialness of modern human rights.

However, the Protestant image of man, in particular, and the Christian image of man, in general, are both open for debate. The radicality of the Protestant tradition to justify sinners through faith alone corresponds with the radicality of the Protestant view of sin. The 'radical evil' (Kant 1983:665-672) is seen as being so radical that even the justified sinner is considered to be justified and a sinner at the same time simul iustus et peccator. At least, this is the paradoxical and vexing way Martin Luther puts it, which is still provocative today. And one has to acknowledge that we will not find the modern idea of human dignity and human rights in the works of Luther, Zwingli or Calvin. In a theological context one must bear in mind that all reasoning on the topic of human dignity by the argument of justification is a relecture and an advancement of reformation theology.

A post-Enlightenment modern consciousness finds it hard to deal with the supposed pessimism of such anthropology, whilst, in the ecumenical dialogue, this radical position of

4.Modern human rights are considered as universal, categorical, individual, equal and impartial (see Lohmann 2010:36f)

5.Cf. Romans 3:10-12, where Paul quotes Psalm 14:1-3. 
Luther also causes considerable problems of understanding. What lies behind the different ways of speaking about the topic of sin? This remains an open question, especially with regard to whether it is only a difference in language or whether it is an unbridgeable theological difference. The struggle over simul iustus et peccator in the context of the 'Joint declaration about the doctrine of justification' of the Lutheran World Federation and the Roman Catholic Church has shown that. ${ }^{6}$

The debate about man and the debate about a theologically appropriate image of man ultimately refer to the debate about God himself. God's existence as well as his goodness and his justice are debatable. This is the problem of theodicy. Theology as 'a science of conflict' (Bayer 1994:105, 505) reflects upon the inner connection between the dispute about God and the dispute about man's existence. ${ }^{7}$ The intertwinement of the theological debate about man and God emerges most clearly in the suffering and death of Jesus Christ, who is the word of God become flesh. It is because of the reciprocal relation of God and men, even in the contradiction of human sin, that the Protestant tradition emphasises the connection between the doctrine of justification of the sinner through faith alone and the problem of theodicy. The justification of the sinner is thus, at the same time, a self-justification of God (i.e. the divine answer to the question if God is just). It is not only human beings who accuse God; rather the existence of the sinful and potentially evil human person brings about the question about the justice of God. What this is aimed at are not only other human beings, but at myself! It is my own existence and my actions, which causes other humans to challenge the justice of God and to doubt his existence.

The saying above the entry to the oracle of Delphi, 'gnothi seauton - know thyself!', is altered in Christianity to become 'Know thyself - face to face with God!' What is meant is not an abstract but rather a concrete, respectively existential, selfknowledge and knowledge of God. As Luther points out in his exegesis of Psalm 51: 'Appropriate object of theology is man as encumbered and lost in sin [homo reus et perditus] and God as the God who justifies and saves the sinner [Deus iustificans vel salvator]. ${ }^{8}$ According to Luther, only the act of justification allows human beings to find full self-knowledge and knowledge of God. Only they who know themselves as justified sinners (i.e. as human persons in need of and participating in forgiveness) truly understand the essence of God, which is ungrounded love. From this vantage point, the world is perceived as the good creation of God; however, knowledge of God might be obscured through the power of sin or through lack of faith.

In the first of the two tales of creation in the Old Testament, God says:

Let us make man in our image, in our likeness, and let them rule over the fish of the sea and the birds of the air, over the livestock,

6.For the state of this ecumenical debate see Schneider and Wenz (2001)

7.Especially the recent Protestant theology, which refers to the theology of reformation and starts its reasoning not by the being of God but by his being in dispute (see Ebeling 1982:169ff).

8.Luther, WA 40/II, 328. See also Calvin, Institutio I, 1,1 over all the earth, and over all the creatures that move along the ground.

The biblical God forms man according to his image and this constitutes the inviolable human dignity. The biblical myth of creation guides readers to see the world and oneself virtually with the eyes of God. As a consequence, the anthropological question about the essence of man and his dignity takes a surprising turn. In Psalm 8 the believer of the Old Testament asks: 'What is man that you are mindful of him, and the son of man that you care for him?' (Ps 8:4). In form of a prayer, the question about the essence of man is not directed at human beings themselves, but at God. The essence of man is determined according to biblical belief through the contrast between his greatness and nothingness, which is mentioned by the psalm, but also that he is the man of God. Humankind's position within the universe is not a result of its special abilities or skills, but of God's grace. It is through thankful and humble amazement that the psalmist asks how man has deserved to be cared for by God. Only such an attitude of amazement, for example in the work of an observing natural scientist or a caring physician, guarantees recognition of human dignity in its entire depth according to theological conviction.

However, to look at the world through the eyes of God, as hinted at in the biblical myth of creation, does not imply that human beings should follow the self-demand of God to create man according his own image. The often mentioned warning of human hubris, which is supposedly the driving force behind biomedical progress, fails to provide a convincing argument. In view of the progress in natural science, technology and medicine, humans possess a responsibility, which cannot simply be denied by referring to the supposed intractability of life. According to anthropological conviction as well as biblical testimony, a crucial dimension of humanity is the necessity for a conscience, that is, an accountable way of dealing with their own lives, as well as the life of others. This manner of dealing also has to be justified ethically; in a theological perspective face to face with God. The question therefore is: what forms of world-handling and self-handling are in accordance with human beings as a creation of God, as well as being created in his image, and what forms contradict it? Part of an ethical and religious way of life is a conscious way of dealing with the human body. Manipulation in the natural constitution of the human person can be in tune with the commitment to God, but can also be in opposition. Medical-technical manipulations are not, as such, an attack on the integrity of creation. To the contrary! They can equally be the practical expression of faithfulness to creation trying to live according to the biblical designation of man under the condition of the scientific-technological age.

\section{Humanity in modern biomedicine after the death of God}

The bioethical discussion shows how difficult it is for human beings to remain human after the supposed end of the Christian God. This does not mean that the idea of human 
dignity can only be founded on Christian convictions; however, the aporias should be noticed when trying to deny the possibility of providing a religious justification. This has been shown by the debate that originated in Peter Sloterdijk's (1999) essay 'Rules for the human park'. In a controversial and possibly wrong-headed interpretation of Martin Heidegger's 'Letter on humanism', Sloterdijk maintains not only the antiquity of man, as we know him, but also the antiquity of the occidental humanism. Moving from Heidegger to Friedrich Nietzsche, but also referring to Plato's Politeia, Sloterdijk (1999:21) interprets the word 'humanism' as the unsuccessful attempt of domesticating man as the 'animal not ascertained'. In view of the new biotechnology, he asks whether self-breeding should take the place of selfdomestication; a new form of 'anthropo-technology' would take the place of old-fashioned humanism and its image of man. A new super-man, indeed a 'super-humanist' (ibid.), would take the place of the old-fashioned human.

Bidding farewell to Christian tradition might be premature; nevertheless, its task is to recover its potential and critical power. The new super-humanists are wrong, if they believe that the eugenical use of gene technology will lead to a final emancipation of human beings from fate. The truth is that progress in the field of medical genetics, as well as predictive and reproductive medicine, lead to new forms of fate. The Christian belief in God, which sees man as the image of God, is not just a version of the belief in fate, as Dworkin (1999) thinks. Rather, in a historical perspective, it leads to a depotentialisation of fate, which determined even the lives of the gods in antiquity. Therefore, the modern denial of the Christian God, put in the formula of the death of God, did not lead to the final liberation of humankind from fate; rather, as the philosopher Odo Marquard puts it, fate returned, that is, fate created new contingencies (Marquard 1980:81).

The development of new contingencies can be witnessed closely in the field of predictive medicine. The gap between the possibilities in the field of diagnosis and the lack of corresponding therapies is ever increasing. The use of predictive methods in the field of prenatal medicine can serve as prophylaxis, but also creates an increasing amount of conflicts of decision. From a theological perspective, it is the free grace of God, which gives human beings their recognition and justification independently of their biology. A new approach to the human dimension of being created in the image of God becomes possible in view of the biotechnological progress; not as a supposed resacralisation of the natural, but rather as a reconstruction of creation in the spirit of justification theology.

The eschatological dimension of the belief of justification, too, has to be considered for questions of bioethics, because it provides a critical view on the latent or open danger of a soteriological interpretation of modern medicine as a doctrine of salvation. On the one hand, the command of charity includes a duty to heal. This command is moreover supported by the healing miracles of Jesus reported in the New Testament, as well as the old idea of Christ medicus
(Honecker 1985; Hübner 1985). On the other hand, all human attempts to heal are put under an eschatological proviso. Eschatology is the Christian doctrine of the Kingdom of God and, respectively, of the perfection of the world through God. Healing (Heilung) and Salvation (Heil) have to be distinguished accordingly. Otherwise, the medical progress runs danger to lead from a spirit of utopia to one of barbarity. The history and especially the medical crimes of the 20th century teach us that the desire to cure humans can equally develop a productive and destructive power. If the 'therapeutic' imperative is misunderstood as a categorical imperative, then medicine can quickly turn inhumane - to the point of unethical human experiments (Kuhlmann 2001:34f).

The ones who are considered incurable are the first victims of the dynamics of a utopian concept of health. The discussions about new forms of selection and of the breeding of humans make it increasingly necessary to defend the right not to be perfect and to stress its positive meaning for humanity in our society.

According to the view of the Protestant tradition, the dignity of the human person is founded in God's pre-established grace, which is even accentuated in the message of the New Testament of the unconditional justification of the sinner. This implies a fundamental distinction between the human person and her good or bad actions (opera). Therefore, the right of life of a human being is not dependent on their intellectual capacities or their physical condition. This follows from the existing connection between the doctrine of justification and Christology. Christian anthropology takes its ideal not from the general idea of man in his perfection but rather from the suffering and crucified Christ, who has 'no beauty or majesty to attract us to him' (Is 53:2). Man as the image of God, as presented by the Christian doctrine of creation, has to be determined from this perspective.

With regard to so-called transhumanism, which aims to change the human species through the use of technology (Gesang 2007; Krüger 2004), it has to be pointed out that Christian anthropology too knows a difference between the old and the new human being. Christian anthropology is also convinced that what we will be has not become apparent. ${ }^{9}$ However, the difference here lies in eschatology, that is it is the reference to the final destination and perfection of the human person, which cannot be achieved by themselves. The old human being in its finitude, in its imperfection and its brokenness, in its failure and its guilt, obtains the unconditional attention and love of God and who should be loved by God's human beings themselves. Even the human person justified through faith by God remains a sinner, such is one of the basic convictions of Protestant anthropology. The justified sinners are unable to better themselves or the world, neither through moral nor through 'anthropotechnology'. The old human in the biblical sense is not in need of perfection but, rather, in need of forgiveness. The word of creation of forgiveness does not make them better, but new.

9.See 1 John 3:2 
This argument could be misunderstood in the way that it amounts to the confusion between soteriology and humanitarian progress. Yet just the opposite is intended. We should accept biomedical progress if it is not understood as a form of self-salvation, thus confusing physical and mental health with salvation and exaggerating medicine to a form of quasi-religion. Also the right not to be perfect must not be interpreted as an argument against biomedical progress in general. On the contrary, biomedical research and progress can be encouraged from a Christian perspective if the aim is to amend the quality of life of persons who suffer illness or disability. But this becomes problematic if a certain understanding of normality leads to discrimination of disabled people. The right to imperfection stands in opposition to every form of paternalism. The sick have the right to refuse therapy and disabled life, as such, has the right to live.

The contribution of Christianity to the anthropological and sociopolitical discussion of the present consists of its ability to show a possibility for dealing with contingencies, which is free of the coercion of the self-produced fate and, respectively, the fate imposed on others. It is the ethos of 'letting be' and mercy, which is based on the conviction that human beings are not owed to themselves.

An understanding of human dignity and of human rights in the perspective of the Pauline doctrine of justification stands critically towards the idea of a declaration of universal human responsibilities as it has been proposed by the catholic theologian Hans Küng and several other prominent authors (Schmidt 1998). They argue that the concept of universal human rights must be supplemented by the idea of universal human responsibilities. To phrase it in theological language, we can say that this concept ignores the distinction between gospel and law. The consequence of this idea might be to undermine the categorical validness of human rights (Körtner 2008:128ff).

The reinterpretation of the Pauline doctrine of justification as developed in this article implies an ethos and an ethics of self-limitation, that is, recognition of all other human beings as having different convictions, religious and moral beliefs. Yet the way in which such a Christian understanding of human dignity comes into practice is not only through selflimitation, but also through benevolence to the others and an appreciation for their basic needs.

\section{References}

Anselm, R., 2001, 'Rechtfertigung und Menschenwürde', in E. Herms (ed.), Menschenbild und Menschenwürde, pp. 471-481, Gütersloher Verlagshaus, Gütersloh.

Bayer, O., 1994, Theologie, Gütersloher Verlagshaus, Gütersloh.

Bedford-Strohm, H., 2008, 'Öffentliche Theologie in der Zivilgesellschaft', in I. Gabriel (ed.), Politik und Theologie in Europa: Perspektiven ökumenischer Sozialethik, pp. 340-366, Matthias Grünewald, Ostfildern.

Bonhoeffer, D., 1998, Widerstand und Ergebung: Briefe und Aufzeichnungen aus der Haft, vol. 8, ed. Chr. Gremmels, E. Bethge \& R. Bethge, in cooperation with I. Tödt and Dietrich Bonhoeffer Works, Gütersloher Verlagshaus, Gütersloh.
Bultmann, R., 1988, Neues Testament und Mythologie: Das Problem der Entmythologisierung in der neutestamentlichen Verkündigung, ed. E. Jüngel, Chr. Kaiser, Munich.

Dabrock, P., Klinnert, L. \& Schardien, S., 2004, Menschenwürde und Lebensschutz: Herausforderungen theologischer Bioethik, Gütersloher Verlagshaus, Gütersloh.

Dworkin, R., 1999, 'Die falsche Angst, Gott zu spielen', DIE ZEIT 38(16.9.1999), 15, 17.

Ebeling, G., 1982, Dogmatik des christlichen Glaubens, vol. 1, 2nd edn., Mohr Siebeck, Tübingen.

Figal, G., 2006, Gegenständlichkeit: Das Hermeneutische und die Philosophie, Mohr Siebeck, Tübingen.

Gesang, B., 2007, Perfektionierung des Menschen, de Gruyter, Berlin.

Gottweis, H. \& Prainsack, B., 2002, 'Religion, Bio-Medizin und Politik', in M. Minkenberg \& U. Willems (eds.), Politik und Religion: Politische Vierteljahresschrift, Special issue $33,412-432$.

Habermas, J., 1988, Nachmetaphysisches Denken: Philosophische Aufsätze, Suhrkamp, Frankfurt.

Habermas, J., 2001a, Die Zukunft der menschlichen Natur: Auf dem Weg zu einer liberalen Eugenik?, Suhrkamp, Frankfurt.

Habermas, J., 2001b, Glauben und Wissen: Friedenspreis des Deutschen Buchhandels, Suhrkamp, Frankfurt.

Habermas, J., 2009, Zwischen Naturalismus und Religion: Philosophische Aufsätze, Suhrkamp, Frankfurt.

Heimbach-Steins, M. \& Steins, G., 2001, 'Ornament, Fundament, Argument oder was sonst? Zur Rolle der Bibel als Kanon in theologischer Ethik und in gemeinsamen katholisch-evangelischen Texten', Zeitschrift für Evangelische Ethik 45, 95-108.

Honecker, M., 1985, 'Christus medicus', Kerygma und Dogma 31, 307-323.

Huber, W. \& Tödt, H.E., 1977, Menschenrechte: Perspektive einer menschlichen Welt, Radius, Stuttgart.

Hübner, J., 1985, 'Christus medicus: Ein Symbol des Erlösungsgeschehens und ein Modell ärztlichen Handelns', Kerygma und Dogma 31, 324-335.

Jonas, H., 1984, Das Prinzip Verantwortung: Versuch einer Ethik für die technologische Zivilisation, Suhrkamp, Frankfurt.

Kant, I., 1983, 'Die Religion innerhalb der Grenzen der bloßen Vernunft', in W. Weischedel (ed.), Kant, Immanuel: Werke in 10 Bänden, vol. 7, 5th edn., Wissenschaftliche Buchgesellschaft, Darmstadt.

Kant, I., 2000, 'Grundlegung zur Metaphysik der Sitten, in W. Weischedel (ed.), Kant, Immanuel: Werkausgabe in 12 Bänden, vol. 8, 12th edn., Suhrkamp, Frankfurt.

Körtner, U., 2004, Unverfügbarkeit des Lebens? Grundfragen der Bioethik und der medizinischen Ethik, 2nd edn., Neukirchener Verlag, Neukirchen-Vluyn.

Körtner, U., 2005, 'Lasset uns Menschen machen': Christliche Anthropologie im biotechnologischen Zeitalter, C.H. Beck, Munich.

Körtner, U., 2008, Evangelische Sozialethik: Grundlagen und Themenfelder, 2nd edn. Vandenhoeck \& Ruprecht, Göttingen.

Körtner, U., 2010, Freiheit und Verantwortung: Studien zur Grundlegung theologischer 2nd edn., Academic Press Fribourg, Freiburg.

Krüger, O., 2004, Virtualität und Unsterblichkeit: Die Visionen des Posthumanismus, Herder, Freiburg.

Kuhlmann, A., 2001, Politik des Lebens - Politik des Sterbens: Biomedizin in der liberalen Demokratie, Fest, Berlin.

Lindemann, A., 2001, 'Schwangerschaftsabbruch als ethisches Problem im antiken Judentum und im frühen Christentum', Wort und Dienst 26, 127-148.

Lohmann, G., 2010, 'Kulturelle Besonderung und Universalisierung der Menschenrechte', in G. Ernst \& S. Sellmaier (eds.), Universelle Menschenrechte und partikulare Moral, Ethik im Diskurs 5, pp. 33-47, Kohlhammer, Stuttgart.

Luther, M., 1930, 'Der Kleine Katechismus', in Rat der Evangelischen Kirche in Deutschland (ed.), Die Bekenntnisschriften der evangelisch-lutherischen Kirche, 6th edn., pp. 501-542, Vandenhoeck \& Ruprecht, Göttingen.

Marquard, O., 1980, Abschied vom Prinzipiellen: Philosophische Studien, Reclam, Stuttgart.

Riha, O., 2002, 'Aktuelle Probleme der Medizin- und', Theologische Literaturzeitung $127,715-728$

Schmidt, H. (ed.), 1998, Allgemeine Erklärung der Menschenpflichten - Ein Vorschlag, Piper, Munich.

Schneider, T. \& Wenz, G. (eds.), 2001, Gerecht und Sünder zugleich? Ökumenische Klärungen, Dialog der Kirchen 11., Herder, Freiburg.

Sloterdijk, P., 1999, 'Regeln für den Menschenpark: Ein Antwortschreiben zum Brief über den Humanismus', DIE ZEIT 38(16.9.1999), 15 \& 18-21.

Utzschneider, H., 2002, 'Der Beginn des Lebens: Die gegenwärtige Diskussion um die Bioethik und das Alte', Zeitschrift für Evangelische Ethik 46, 135-143

Watson, J., 2001, 'Die Ethik des Genoms : Warum wir Gott nicht mehr die Zukunft des Menschen überlassen dürfen', Frankfurter Allgemeine Zeitung 224(26.9.2000), 55.

Wetz, F.J., 1998, Die Würde der Menschen ist antastbar: Eine Provokation, Klett, Stuttgart. 